\title{
Commentary: Phyllostomid bat microbiome composition is associated to host phylogeny and feeding strategies
}

\author{
Arinjay Banerjee ${ }^{1}$, Edel Pérez-López ${ }^{2}$ and Karen Mossman ${ }^{1 *}$ \\ ${ }^{1}$ Department of Pathology and Molecular Medicine, Faculty of Health Sciences, Michael DeGroote Centre for Learning and \\ Discovery, McMaster University, Hamilton, ON, Canada, ${ }^{2}$ Department of Biology, University of Saskatchewan, Saskatoon, \\ SK, Canada
}

Keywords: bat, microbiome, sentinel, phytoplasma, plant pathogen

\section{A Commentary on}

Phyllostomid bat microbiome composition is associated to host phylogeny and feeding strategies

OPEN ACCESS

Edited by:

Boran Kartal,

Max Planck Institute for Marine

Microbiology (MPG), Germany

Reviewed by:

Caleb Dakotah Phillips,

Texas Tech University, United States

*Correspondence:

Karen Mossman

mossk@mcmaster.ca

Specialty section:

This article was submitted to

Evolutionary and Genomic

Microbiology,

a section of the journal

Frontiers in Microbiology

Received: 15 October 2018 Accepted: 06 November 2018 Published: 22 November 2018

Citation:

Banerjee A, Pérez-López E and Mossman K (2018) Commentary:

Phyllostomid bat microbiome composition is associated to host phylogeny and feeding strategies.

Front. Microbiol. 9:2863.

doi: 10.3389/fmicb.2018.02863 by Carrillo-Araujo, M., Tas, N., Alcantara-Hernandez, R. J., Gaona, O., Schondube, J. E., Medellin, R. A., et al. (2015). Front. Microbiol. 6:447. doi: 10.3389/fmicb.2015.00447

In their article, Carrillo-Araujo et al. show that Phyllostomidae (New World leaf-nosed bat family) gut microbiome composition is closely associated with host phylogeny. They provide evidence that feeding-strategy plays a role in the microbiome composition of these bats (Carrillo-Araujo et al., 2015). We were particularly intrigued by their detection of deoxyribonucleic acid (DNA) from Firmicutes in intestinal sections from these bats. The authors use a previously published approach of sequencing 16s rRNA for taxonomic assignment of the microbial community (Caporaso et al., 2012). 16s rRNA is a good predictor of taxonomic classification (Mizrahi-Man et al., 2013; Chaudhary et al., 2015), but it is not foolproof (reviewed here by Janda and Abbott, 2007). Data on the probability of correct taxonomic assignment will bolster the findings in this article and allow researchers to confidently design follow-up studies. Although not necessary for this study, testing a subset of the microbial population using an alternate sequencing-taxonomic grouping pipeline would further substantiate the taxonomic classification of microbial communities.

Mollicutes (Phylum Firmicutes) are a class of microorganisms that include phytoplasmas ('Candidatus Phytoplasma') that are being increasingly recognized for their role in plant diseases such as sapodilla little leaf, yellow leaf roll disease of peach, strawberry green petal and sugarcane white leaf syndrome. These diseases affect a diverse array of economically and ecologically important plant hosts around the world (Vesterinen et al., 2013; Pérez-López et al., 2016, 2017). Mollicutes are highly diverse and are made up of five orders, Acholeplasmatales, Anaeroplasmatales, Entoplasmatales, Haloplasmatales, and Mycoplasmatales. All members of these orders are obligate parasites. Genera 'Candidatus Phytoplasma' and Spiroplasma, from the Order Acholeplasmatales and Entoplasmatales, respectively, consist of plant pathogens. 'Candidatus Phytoplasma' and Spiroplasma represent 18\% of the Class Mollicutes (Zhao et al., 2015).

'Candidatus Phytoplasma' consists of over 40 species that are known to be pathogenic in plants (Miyazaki et al., 2018). In the Genus Spiroplasma, at least two species have been identified as plant pathogens, Spiroplasma citri, the causative agent of citrus stubborn disease (Saglio et al., 1973) and Spiroplasma kunkelii, which is associated with corn stunt disease (Whitcomb et al., 1986). 
A

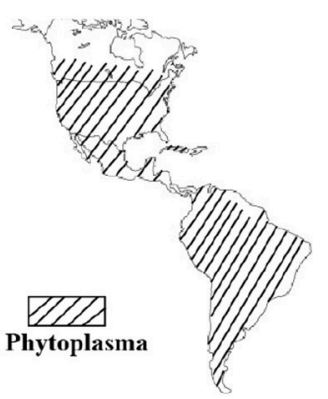

E

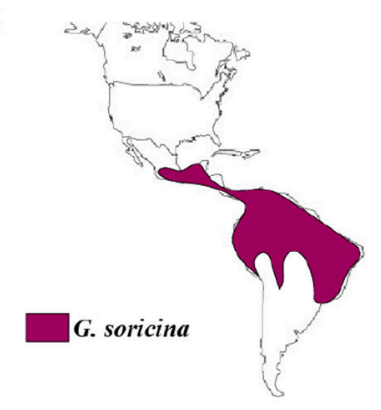

B
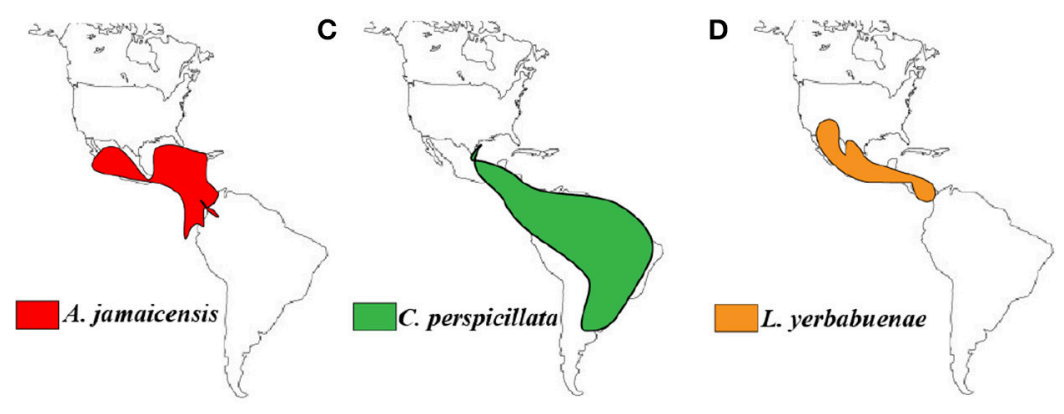

$\mathbf{F}$

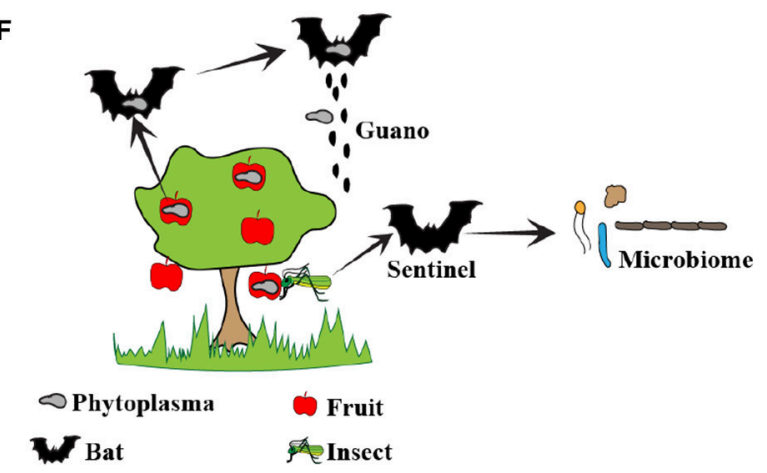

FIGURE 1 | Distribution of phytoplasmas and bats. (A) Phytoplasma distribution in the Americas (Lee et al., 2000; Pérez-López et al., 2016). (B-E) Geographical distribution of A. jamaicensis (Miller et al., 2016), C. perspicillata (Barquez et al., 2015a), L. yerbabuenae (Medellin, 2016), and G. soricina (Barquez et al., 2015b; IUCN, 2018) sampled in this study by Carrillo-Araujo et al. (F) Schematic representation of the possible role of bats as vectors and sentinels of phytoplasmas. Fruit and nectivorous bats could potentially move phytoplasmas around through guano or seeds that are part of the guano. Alternatively, microbiome analysis of insectivorous bats that feed on fruit eating insects could allow us to monitor phytoplasma prevalence and spread.

In their article, the authors indicate that Artibeus jamaicensis have the highest relative abundance of Mollicutes in their intestinal contents (Carrillo-Araujo et al., 2015). In their article, supplementary Table S1 also indicates the presence of nucleic acids from Firmicutes in all bat species that were sampled. Looking at their data from a plant disease perspective, we wondered if frugivorous and nectivorous bats could play a role in the transmission of plant pathogens. Could this data set and the sampling methods established allow us to monitor bats as sentinels of plant pathogens? Here, we speculate upon the role of frugivorous and nectivorous bats as possible vectors of plant pathogens. We outline limitations of this study that do not allow us to fully establish the dynamics of plant pathogen-bat interactions. We also discuss future directions to firmly establish the role of bats as potential vectors of plant pathogens.

Recently, bats have been implicated as the reservoirs of several emerging viruses that cause serious disease in humans and agricultural animals (Calisher et al., 2006; Moratelli and Calisher, 2015; Zhou et al., 2018). These viruses fail to cause disease symptoms in experimentally or naturally infected bats (Munster et al., 2016; Hu et al., 2017; Schuh et al., 2017). We and others have since identified several adaptations in innate immune signaling molecules that might allow bats to control virus propagation more effectively than other mammals (Zhou et al., 2016; Banerjee et al., 2017; Xie et al., 2018). Bats are also recognized as potential reservoirs of pathogenic bacteria (Loftis et al., 2005; Becker et al., 2018). Plant pathogens do not generally infect mammalian hosts, but after careful analysis of the data in Carrillo-Araujo et al.'s article (Carrillo-Araujo et al., 2015), the role of bats as potential vectors/carriers of plant pathogens cannot be ruled out. We compared the extent of spread of phytoplasmas in the Americas (Figure 1A) and observed that it overlapped with the spread of frugivorous bats A. jamaicensis (Figure 1B) and Carollia perspicillata (Figure 1C) and nectivorous bats Leptonycteris yerbabuenae (Figure 1D) and Glossophaga soricina (Figure 1E) that were sampled by the authors. The authors mention that frugivorous and nectivorous bats diverged 20-18 million years ago (MYA). Evolutionary reconstructions show that the divergence of Mollicutes into two major branches occurred about 470 MYA, placing phytoplasmas and their closest ancestor, Ancholeplasma in the same branch (Maniloff, 2002). There is further evidence that phytoplasmas diverged from an Acholeplasma-like ancestor around 99 MYA (Zhao et al., 2015). Thus, phytoplasmas and frugivorous bats have co-existed for at least 18 million years. Could bats have acquired phytoplasmas as part of their microbiome after their divergence into frugivorous and nectivorous bats? Could bats have played a role in the spread of phytoplasmas? We do not know. Phytoplasmas have been detected in fruits in the United States and Canada (Bagadia et al., 2013; Rosete et al., 2015). There is a need to sample additional bat species to 
fully elucidate the overlap in the spread of phytoplasmas and frugivorous bats.

Multiple studies have established the role of bats as reservoirs of certain mammalian viruses (Corman et al., 2014; Plowright et al., 2016; Ng and Tan, 2017; Noh et al., 2017; Widagdo et al., 2017). Similar studies are needed for plant pathogens. In this study, the authors analyzed the microbiome of bats using DNA sequencing. The ability to culture Mollicutes from bat intestinal samples would identify if these bacteria remain viable while they pass through the harsh environment of the digestive tract. Unfortunately, many of the plant pathogenic Mollicutes, including phytoplasmas, are unculturable in axenic media. Although Mollicutes are unlikely to replicate in bat gut cells, they could potentially proliferate within the intestinal micro-community. However, this remains to be tested.

Other questions about the possible excretion of viable bacteria through bat guano and the ability to infect plants remain unknown (Figure 1F). Seeds could be part of bat guano, but phytoplasma transmission through seeds has not been confirmed or disproved yet. Alongside birds, bats are capable of true flight. The possibility to deposit phytoplasma-contaminated guano from one area to another and within the same area is high. Aryan et al. showed that phytoplasmas are transmissible through graft (Aryan et al., 2016). Thus, mechanical transmission is another possibility. This form of transmission occurs when

\section{REFERENCES}

Aryan, A., Musetti, R., Riedle-Bauer, M., and Brader, G. (2016). Phytoplasma transmission by heterologous grafting influences viability of the scion and results in early symptom development in periwinkle rootstock. J. Phytopathol. 164, 631-640. doi: 10.1111/jph.12486

Bagadia, P. G., Polashock, J., Bottner-Parker, K. D., Zhao, Y., Davis, R. E., and Lee, I. M. (2013). Characterization and molecular differentiation of 16SrI-E and 16SrIX-E phytoplasmas associated with blueberry stunt disease in New Jersey. Mol. Cell. Probes 27, 90-97. doi: 10.1016/j.mcp.2012.11.002

Banerjee, A., Rapin, N., Bollinger, T., and Misra, V. (2017). Lack of inflammatory gene expression in bats: a unique role for a transcription repressor. Sci. Rep. 7:2232. doi: 10.1038/s41598-017-01513-w

Barquez, R., Perez, S., Miller, B., and Diaz, M. (2015a). Carollia perspicillata. The IUCN Red List of Threatened Species [Online]. Available online at: https://www. iucnredlist.org/species/3905/22133716 (Accessed October 17, 2018).

Barquez, R., Perez, S., Miller, B., and Diaz, M. (2015b). Glossophaga soricina. The IUCN Red List of Threatened Species [Online]. Available online at: https://www. iucnredlist.org/species/9277/22107768 (Accessed October 17, 2018).

Becker, D. J., Bergner, L. M., Bentz, A. B., Orton, R. J., Altizer, S., and Streicker, D. G. (2018). Genetic diversity, infection prevalence, and possible transmission routes of Bartonella spp. in vampire bats. PLoS Negl. Trop. Dis. 12:e0006786. doi: 10.1371/journal.pntd.0006786

Calisher, C. H., Childs, J. E., Field, H. E., Holmes, K. V., and Schountz, T. (2006). Bats: important reservoir hosts of emerging viruses. Clin. Microbiol. Rev. 19, 531-545. doi: 10.1128/CMR.00017-06

Caporaso, J. G., Lauber, C. L., Walters, W. A., Berg-Lyons, D., Huntley, J., Fierer, N., et al. (2012). Ultra-high-throughput microbial community analysis on the Illumina HiSeq and MiSeq platforms. ISME J. 6, 1621-1624. doi: 10.1038/ismej.2012.8

Carrillo-Araujo, M., Taş, N., Alcántara-Hernández, R. J., Gaona, O., Schondube, J. E., Medellín, R. A., et al. (2015). Phyllostomid bat microbiome composition feeding animals cause tissue damage in plants, aiding the spread of microorganisms.

While bats are speculated as reservoirs of multiple microbes, this study brings up the possibility of using bat microbiome data as predictors of pathogen spread and prevalence (Figure 1F). Although our knowledge about the bat microbiome is limited, it does provide us with an opportunity to study bats as sentinels of plant pathogens. This opportunity extends to insect-eating bats, since insects such as leafhoppers and planthoppers are known vectors for phytoplasmas (Weintraub and Beanland, 2006; Pérez-López et al., 2018).

Future studies focused on identifying neglected vectors of plant pathogens will elucidate the likely role played by herbivorous wildlife in the dispersal of these microorganisms. Results from such studies will have agricultural policy implications for plant diseases. Phytoplasmas continue to cause losses to local farmers and has an impact on the economy. In our opinion, this study by Carrillo-Araujo et al. that identified Mollicutes in the intestinal content of Phyllostomid bats opens up an alternate and intriguing line of investigation in to wildlife vectors and sentinels of plant pathogens.

\section{AUTHOR CONTRIBUTIONS}

$\mathrm{AB}$ and EP-L wrote the commentary. KM edited the commentary. is associated to host phylogeny and feeding strategies. Front. Microbiol. 6:447. doi: $10.3389 /$ fmicb.2015.00447

Chaudhary, N., Sharma, A. K., Agarwal, P., Gupta, A., and Sharma, V. K. (2015). 16S classifier: a tool for fast and accurate taxonomic classification of $16 \mathrm{~S}$ rRNA hypervariable regions in metagenomic datasets. PLoS ONE 10:e0116106. doi: 10.1371/journal.pone.0116106

Corman, V. M., Ithete, N. L., Richards, L. R., Schoeman, M. C., Preiser, W., Drosten, C., et al. (2014). Rooting the phylogenetic tree of middle East respiratory syndrome coronavirus by characterization of a conspecific virus from an African bat. J. Virol. 88, 11297-11303. doi: 10.1128/JVI.01498-14

Hu, B., Zeng, L. P., Yang, X. L., Ge, X. Y., Zhang, W., Li, B., et al. (2017). Discovery of a rich gene pool of bat SARS-related coronaviruses provides new insights into the origin of SARS coronavirus. PLoS Pathog. 13:e1006698. doi: 10.1371 /journal.ppat.1006698

IUCN (2018). The IUCN Red List of Threatened Species. Version 2018-1. [Online]. Available online at: http://www.iucnredlist.org (Accessed October 10, 2018).

Janda, J. M., and Abbott, S. L. (2007). 16S rRNA gene sequencing for bacterial identification in the diagnostic laboratory: pluses, perils, and pitfalls. J. Clin. Microbiol. 45, 2761-2764. doi: 10.1128/JCM.01228-07

Lee, I. M., Davis, R. E., and Gundersen-Rindal, D. E. (2000). Phytoplasma: phytopathogenic mollicutes. Annu. Rev. Microbiol. 54, 221-255. doi: 10.1146/annurev.micro.54.1.221

Loftis, A. D., Gill, J. S., Schriefer, M. E., Levin, M. L., Eremeeva, M. E., Gilchrist, M. J., et al. (2005). Detection of rickettsia, borrelia, and bartonella in Carios kelleyi (Acari: Argasidae). J. Med. Entomol. 42, 473-480. doi: 10.1603/00222585(2005)042 [0473:DORBAB]2.0.CO;2

Maniloff, J. (2002). "Phylogeny and evolution," in Molecular Biology and Pathogenicity of Mycoplasmas, eds S. Razin and R. Herrmann ( Boston, MA: Springer), 31-43. doi: 10.1007/0-306-47606-1_2

Medellin, R. (2016). Leptonycteris yerbabuenae. The IUCN Red List of Threatened Species 2016 [Online]. Available online at: https://www.iucnredlist.org/species/ 136659/21988965 (Accessed October 17, 2018). 
Miller, B., Reid, F., Arroyo-Cabrales, J., Cuaron, A. D., and De Grammont, P. C. (2016). Artibeus jamaicensis. The IUCN Red List of Threatened Species [Online]. Available online at: https://www.iucnredlist.org/species/88109731/ 21995883 (Accessed October 17, 2018).

Miyazaki, A., Shigaki, T., Koinuma, H., Iwabuchi, N., Rauka, G. B., Kembu, A., et al. (2018). 'Candidatus Phytoplasma noviguineense', a novel taxon associated with Bogia coconut syndrome and banana wilt disease on the island of New Guinea. Int. J. Syst. Evol. Microbiol. 68, 170-175. doi: 10.1099/ijsem.0.002480

Mizrahi-Man, O., Davenport, E. R., and Gilad, Y. (2013). Taxonomic classification of bacterial 16S rRNA genes using short sequencing reads: evaluation of effective study designs. PLoS ONE 8:e53608. doi: 10.1371/journal.pone.0053608

Moratelli, R., and Calisher, C. H. (2015). Bats and zoonotic viruses: can we confidently link bats with emerging deadly viruses? Mem. Inst. Oswaldo Cruz 110, 1-22. doi: 10.1590/0074-02760150048

Munster, V. J., Adney, D. R., Van Doremalen, N., Brown, V. R., Miazgowicz, K. L., Milne-Price, S., et al. (2016). Replication and shedding of MERS$\mathrm{CoV}$ in Jamaican fruit bats (Artibeus jamaicensis). Sci. Rep. 6:21878. doi: $10.1038 /$ srep 21878

Ng, O. W., and Tan, Y. J. (2017). Understanding bat SARS-like coronaviruses for the preparation of future coronavirus outbreaks - Implications for coronavirus vaccine development. Hum. Vaccin. Immunother. 13, 186-189. doi: 10.1080/21645515.2016.1228500

Noh, J. Y., Yoon, S. W., Kim, D. J., Lee, M. S., Kim, J. H., Na, W., et al. (2017). Simultaneous detection of severe acute respiratory syndrome, Middle East respiratory syndrome, and related bat coronaviruses by real-time reverse transcription PCR. Arch. Virol. 162, 1617-1623. doi: 10.1007/s00705-017-3281-9

Pérez-López, E., Luna-Rodriguez, M., Olivier, C. Y., and Dumonceaux, T. J. (2016). The underestimated diversity of phytoplasmas in Latin America. Int. J. Syst. Evol. Microbiol. 66, 492-513. doi: 10.1099/ijsem.0.000726

Pérez-López, E., Rodríguez-Martínez, D., Olivier, C. Y., Luna-Rodríguez, M., and Dumonceaux, T. J. (2017). Molecular diagnostic assays based on cpn60 UT sequences reveal the geographic distribution of subgroup 16SrXIII-(A/I)I phytoplasma in Mexico. Sci. Rep. 7:950. doi: 10.1038/s41598-017-00895-1

Pérez-López, E., Wist, T., Dumonceaux, T., Luna-Rodríguez, M., Nordin, D., Castro-Luna, A., et al. (2018). Detection of maize bushy stunt phytoplasma in leafhoppers collected in native corn crops grown at high elevations in Southeast Mexico. Florida Entomol. 101, 12-19. doi: 10.1653/024.10 1.0104

Plowright, R. K., Peel, A. J., Streicker, D. G., Gilbert, A. T., Mccallum, H., Wood, J., et al. (2016). Transmission or within-host dynamics driving pulses of zoonotic viruses in reservoir-host populations. PLoS Negl. Trop. Dis. 10:e004796. doi: 10.1371/journal.pntd.0004796

Rosete, Y. A., Schilder, A., Lambert, L., and Scott, J. (2015). Identification and molecular characterization of the blueberry stunt phytoplasma in Canada. Phytopathogen. Mollicutes 5, S17-S18. doi: 10.5958/2249-4677.2015.00006.7
Saglio, P., Lhospital, M., Lafleche, D., Dupont, G., Bove, J. M., Tully, J. G., et al. (1973). Spiroplasma citri gen. and sp. n.: a mycoplasma-like organism associated with "stubborn" disease of citrus. Int. J. Syst. Bacteriol. 23, 191-204. doi: 10.1099/00207713-23-3-191

Schuh, A. J., Amman, B. R., Jones, M. E., Sealy, T. K., Uebelhoer, L. S., Spengler, J. R., et al. (2017). Modelling filovirus maintenance in nature by experimental transmission of Marburg virus between Egyptian rousette bats. Nat. Commun. 8:14446. doi: $10.1038 /$ ncomms 14446

Vesterinen, E. J., Lilley, T., Laine, V. N., and Wahlberg, N. (2013). Next generation sequencing of fecal DNA reveals the dietary diversity of the widespread insectivorous predator Daubenton's Bat (Myotis daubentonii) in Southwestern Finland. PLoS ONE 8:e82168. doi: 10.1371/journal.pone.0082168

Weintraub, P. G., and Beanland, L. (2006). Insect vectors of phytoplasmas. Annu. Rev. Entomol. 51, 91-111. doi: 10.1146/annurev.ento.51.110104.151039

Whitcomb, R. F., Chen, T. A., Williamson, D. L., Liao, C., Tully, J. G., Bove, J. M., et al. (1986). Spiroplasma kunkelii sp. nov.: characterization of the etiological agent of corn stunt disease. Int. J. Syst. Bacteriol. 36, 170-178. doi: 10.1099/00207713-36-2-170

Widagdo, W., Begeman, L., Schipper, D., Run, P. R. V., Cunningham, A. A., Kley, N., et al. (2017). Tissue distribution of the MERS-coronavirus receptor in bats. Sci. Rep. 7:1193. doi: 10.1038/s41598-017-01290-6

Xie, J., Li, Y., Shen, X., Goh, G., Zhu, Y., Cui, J., et al. (2018). Dampened STINGdependent interferon activation in bats. Cell Host Microbe 23, 297-301.e294. doi: 10.1016/j.chom.2018.01.006

Zhao, Y., Davis, R. E., Wei, W., and Lee, I. M. (2015). Should 'Candidatus Phytoplasma' be retained within the order Acholeplasmatales? Int. J. Syst. Evol. Microbiol. 65, 1075-1082. doi: 10.1099/ijs.0.000050

Zhou, P., Fan, H., Lan, T., Yang, X. L., Shi, W. F., Zhang, W., et al. (2018). Fatal swine acute diarrhoea syndrome caused by an HKU2-related coronavirus of bat origin. Nature 556, 255-258. doi: 10.1038/s41586-018-0010-9

Zhou, P., Tachedjian, M., Wynne, J. W., Boyd, V., Cui, J., Smith, I., et al. (2016). Contraction of the type I IFN locus and unusual constitutive expression of IFN-alpha in bats. Proc. Natl. Acad. Sci. U.S.A. 113, 2696-2701. doi: $10.1073 /$ pnas. 1518240113

Conflict of Interest Statement: The authors declare that the research was conducted in the absence of any commercial or financial relationships that could be construed as a potential conflict of interest.

Copyright (C) 2018 Banerjee, Pérez-López and Mossman. This is an open-access article distributed under the terms of the Creative Commons Attribution License (CC BY). The use, distribution or reproduction in other forums is permitted, provided the original author(s) and the copyright owner(s) are credited and that the original publication in this journal is cited, in accordance with accepted academic practice. No use, distribution or reproduction is permitted which does not comply with these terms. 